ORIGINAL ARTICLE

\title{
Jehovah's Witnesses in the emergency department: what are their rights?
}

\section{S Woolley}

Emerg Med J 2005;22:869-871. doi: 10.1136/emj.2004.023382

The Jehovah's Witnesses Society is best known to outsiders for its refusal of blood products, even when such a refusal may result in death. Since the introduction of the blood ban in 1945, Jehovah's Witness (JW) parents have fought for their rights to refuse blood on behalf of their children, based on religious beliefs and their right to raise children as they see fit. Adolescent JWs have also sought to refuse blood products based on their beliefs, regardless of the views of their parents. Adult JWs have fought to protect their autonomy when making both contemporaneous and advance treatment refusal. The refusal of blood products by JWs raises ethical and legal dilemmas that are not easily answered. Do an individual's rights (namely bodily control, right to privacy, right to decide about life/death issues, right to religious freedom) outweigh society's rights (namely the preservation of life, the prevention of suicide, the protection of innocent third parties, and the maintenance of the ethical integrity of the medical profession)? Does the right to choose outweigh the value of human life? For doctors, conflict occurs between the desire to respect patient autonomy and the need to provide good medical care. The Watchtower Society (the JW governing body) imposes a strict code of moral standards among its members, and it is unlikely that individual JWs are making truly autonomous decisions about blood transfusions. While young children and adolescents are protected by the courts and conscious adults are afforded autonomy, dilemmas still arise in the emergency situation. This article examines the rights of young children, adolescents, and adults, focusing in the latter half on adults in the emergency situation.

Correspondence to: Dr S Woolley, Bristol Roya Infirmary/Bristol Royal Hospital for Children, Upper Maudlin Street Bristol, UK; woolley_s@ hotmail.com

Accepted for publication 21 February 2005
$\mathrm{T}$ he Jehovah's Witness Society (JW), based in New York, is an international religious organisation, the followers of which believe the Bible is the true word of God. ${ }^{1}$ To many people, the Society is best known for its absolute prohibition on the acceptance of blood transfusions, based on the belief that transfused blood is a nutrient, ${ }^{2}$ and that three Biblical passages allegedly forbid transfusion. ${ }^{3}$ In the emergency department (ED), refusal by a JW to accept blood products creates ethical and legal dilemmas. This article discusses the rights of both patients and healthcare professionals in the context of the ED.

\section{YOUNG CHILDREN}

Traditionally, when children are incompetent, the power to give or withhold consent to medical treatment on their behalf lies with those with parental responsibility. Legally, except in an emergency, parental consent is necessary to perform any medical procedure on an incompetent child. While courts throughout the western world recognise these parental rights, they are not absolute. ${ }^{4}$ The right to raise children is qualified by a duty to ensure their health, safety, and wellbeing. ${ }^{5}$ Parents cannot make decisions that may permanently harm or otherwise impair their healthy development: ${ }^{67}$

\footnotetext{
"Parents may be free to become martyrs themselves. But it does not follow that they are free, in identical circumstances, to make martyrs of their children... ${ }^{1 / 8}$
}

There is, therefore, no legal debate about the ability of parents to refuse blood on their children's behalf when blood products are clinically indicated. Since the Watchtower Society (WTS), the JW governing body, introduced the blood ban in 1945, courts in the USA, ${ }^{9}$ the UK, ${ }^{10}$ and Australia ${ }^{11}$ have made it clear that parents cannot refuse blood on their children's behalf, based on three main principles: $(a)$ the child's interests and those of the state outweigh parental rights to refuse medical treatment; ${ }^{12}(b)$ parental rights do not give parents life and death authority over their children; ${ }^{13}$ and (c) parents do not have an absolute right to refuse medical treatment for their children based on their religious beliefs ${ }^{14}$ if that refusal is regarded as unreasonable.

\section{ADOLESCENTS}

The situation regarding the ability of mature minors to refuse medical treatment is not as straightforward. In Canada, despite pre-1996 court decisions ${ }^{15}$ supporting the notion of adolescent autonomy, adolescents may not refuse medical treatment. ${ }^{16}$ In the USA, three states recognise the "mature minor" concept ${ }^{17}$ but elsewhere adolescents rely on parental decision making. In England and Wales, mature minors may consent to, but may not necessarily be able to refuse, treatment. In Scotland, although not specifically referred to, the Age of Legal Capacity Act $^{18}$ implies that a competent child may refuse, as well as accept, treatment.

The debate commenced in 1985 with Gillick $v$ West Norfolk. ${ }^{19}$ The majority of the House of Lords were clear that if a child under 16 years could demonstrate sufficient understanding and intelligence to fully understand the treatment proposed they could give their consent to treatment. ${ }^{19}$ Unfortunately this case did not address the issue of treatment refusal. Subsequent $\operatorname{cases}^{20}$ may possibly be seen as undermining the ability of minors to make decisions about the refusal of medical treatment, as in each case the court has exercised its right to overrule the decisions of minors "in the best interests" of the child. In all cases concerning adolescent $\mathrm{JWs}^{21}{ }^{21}$ the courts have allowed transfusion, with the judges expressing concern about the child's ability to make a fully informed

Abbreviations: JW, Jehovah's Witnesses; WTS, Watchtower Society 
decision because of their sheltered upbringing and the influence of the JW faith.

\section{ADULTS}

Although the state has an interest in the preservation of life, that interest is not absolute. Individuals have the right to control their own person and part of that autonomy is the "right to make choices pertaining to one's health, including the right to refuse unwanted medical treatment". ${ }^{22}$ Although this right should encompass all medical choices, including the refusal of blood products, JWs have had to defend this right in the courts.

Although there are no UK cases concerning competent non-pregnant adult JWs, cases have appeared before the courts in the USA since $1964 .{ }^{23}$ These cases focus primarily on an individual's rights versus state interests. Earlier cases $^{24}$ placed the state's interest before an individual's right to refuse unwanted medical treatment and subsequent cases have used a variety of arguments to transfuse adults against their wishes. ${ }^{25-28}$ However, in 1985 the appeal court in In Re $B_{\text {Brown }}{ }^{29}$ ended the debate with a strong statement supporting an individual's right to refuse medical treatment:

\section{"Rights are subject to compromise only when they collide with conflicting rights vested in others... The right of free exercise of religion protects more than mere beliefs... Religiously grounded actions or conduct are often beyond the authority of the state to control...". ${ }^{30}$}

This statement is supported by subsequent cases, ${ }^{31}$ and gives competent adult JWs the right to refuse unwanted blood products, even in the USA.

\section{THE EMERGENCY SITUATION}

Unconscious JWs, with signed blood refusal cards, a form of advance directive, create medical, ethical, and legal dilemmas for healthcare professionals. English law is clear and unequivocal. Patients have the right to refuse medical treatment "for reasons which are rational or irrational or for no reason" ${ }^{\prime \prime 2}$ and "even in circumstances where she is...certain to die in the absence of treatment" ${ }^{\prime 3}$ This absolute principle is applicable to a competent patient's anticipatory refusal of consent in the form of an "advance directive" or "living will". ${ }^{33}$ Anticipatory refusals should ideally fulfil certain criteria. ${ }^{3435}$ and there is concern that the blood refusal cards carried by JWs may not meet these criteria.

Since the 1970s, JWs have carried WTS distributed blood refusal cards. These cards specify that the owner will not accept blood products under any circumstances. Although theoretically, refusal is religiously motivated, the card recognises risks associated with blood, ${ }^{36}$ making it essential that treating physicians are satisfied that JWs have enough information regarding the risks and benefits of blood transfusion to make a decision to refuse it.

In an emergency, the doctor must be satisfied that a card carrying JW has been provided with the information necessary to make an informed decision. This is unlikely, as the WTS ${ }^{37}$ provides information about the risks but not the benefits of blood. In addition to the possible lack of information there is also concern about whether an individual's decision to carry a card is without external influence (crucial when considering autonomy). The WTS decides which products JWs may accept, distributes the "boilerplate" cards annually, and initiates the card signing process. Disfellowshipping (a form of excommunication) is the penalty for accepting blood products, and thus it is unlikely that a decision to sign a blood refusal card is without external influence.
What, therefore, should doctors do in the emergency situation? In an emergency, treatment that is in the patient's best interests may be given under the doctrine of necessity. However, this doctrine assumes that "under the circumstances, a reasonable person would consent, and thus the probabilities are that the patient would consent". ${ }^{38}$ This doctrine is unlikely to apply to JWs, as most, if conscious, would object to treatment. ${ }^{39}$

Unfortunately, the two leading legal cases $^{40}$ considering unconscious JWs offer conflicting advice. In Dorone, ${ }^{41}$ the Supreme Court upheld a decision to allow transfusion, ${ }^{42}$ whereas in Malette, ${ }^{43}$ the physician was found liable for battery. The standard in Dorone ${ }^{40}$ essentially precludes application of any form of advance directive. Conversely, the court in Malette $^{43}$ accepted the undated, unwitnessed card at face value. ${ }^{44}$ The latter approach is not ideal; the decision was retrospective and it would be impossible to know whether the pre-printed wishes still reflected the patient's views.

HE $v$ a Hospital NHS Trust ${ }^{45}$ resolved these issues. A Muslim born woman who had converted to the JW faith following her parents' divorce required life saving medical treatment for congenital heart disease. Shortly after her conversion, she signed a blood refusal card. Her father argued that this card should not be valid because: the girl was now engaged to a Muslim man and had consequently rejected her faith as a JW, she had not attended any JW meetings in the preceding 4 months, her advance directive predated her change in faith, and she had not mentioned the advance directive while conscious. The court accepted these arguments, adopting the approach in Dorone: ${ }^{41}$

\section{"There are no formal requirements for a valid advance directive... There are no formal requirements for the revocation of an advanced directive... An advance directive is inherently revocable... The burden of proof is on those who seek to establish the existence and continuing validity and applicability of an advance directive... If there is doubt, that doubt falls to be resolved in favour of the preservation of life". ${ }^{45}$}

Therefore, in the emergency situation, if doubt exists about the validity of a blood refusal card, physicians should aim to preserve life and administer the necessary blood products.

\section{CONCLUSION}

JWs presenting to the ED continue to cause concern. However, the law regarding young children, adolescents, and adults (in the non-emergency situation) is clear: parents may not refuse blood on their children's behalf if such a refusal is deemed unreasonable, adolescents cannot necessarily refuse blood, and competent adults can refuse unwanted treatment.

In an emergency, the situation is more complex, particularly as there are concerns about how informed individual JWs are about the risks/benefits of blood. Physicians should provide the necessary information for an individual to make an informed choice and where this is not possible, physicians should administer blood products in life threatening situations, if any doubt exists about the validity of a blood refusal card.

Competing interests: none declared

\section{REFERENCES}

1 Harrison BG. Visions of glory: a history and memory of Jehovah's Witnesses. New York: Simon and Schuster, 1978.

2 Anonymous. "A patient in hospital may be fed through the mouth, through the nose or through the veins. When sugar solutions are given intravenously, it is called intravenous feeding. So the hospital's own terminology recognizes as 
feeding the process of putting nutrition into one's system via the veins. Hence the attendant administering the transfusion is feeding the patient blood through the veins, and the patient receiving it is eating through his veins. "The Watchtower 1951; July:415.

3 The Bible. Genesis 9:4, Leviticus 17:11-14, and Acts 15:20, 29

4 Parental rights not absolute: Newmark v Williams 588 A.2d 1108 (Del. 1991), Jacobson v Massachusetts 197 US 11 (1905), Hawaii v Standard Oil Co. 405 US 251 (1972); Rejection of the Free Exercise Clause: Prince v Massachusetts (1944) 321 US 158, Walker v Superior Court 763 P, 2d 852 (1988), Commonwealth v Barnhardt 497 A.2d 616 (Pa.Super. 1985), Craig v State 220 Md.590 (1959), People v Pierson 176 NY 201 (1903), State v Norman 808 P.2d 1159 (Wash.Ct.App.1991), Funkhauser v State 763 P.2d 695 (1988), Commonwealth v Nickson 718 A.2d 311 (Pa.Super.Ct. 1998), In Re Custody of a Minor 379 NE.2d 1053 (Mass. 1978), Commonwealth v Twitchell 617 NE.2d 609 (Mass. 1993).

5 CYPA 1933, sections (1) and (2)(a) but liability here is not as a parent but as a person over 16 having the 'custody, charge or care' of a child under 16.

6 Dwyer JG. The children we abandon: religious exemption to child welfare and education laws as denials of equal protection to children of religious objectors. North Carolina L Rev 1996;74:1321.

7 Queensland Law Reform Commission. Consent to medical treatment of young people. Discussion paper 34-35 1995.

8 Prince $v$ Massachusetts (1944) 321 US 158 at 170.

9 People ex rel. Wallace et al. v Labrenz et al., 104 N.E.2d 769 (IL 1952), Morrison v State 252 S.W.2d 97 (MO C. of A. 1952), State v Perricone 181 A.2d 751 (NJ 1962), Hoener v Bertinato 171 A.2d 140 (NJ Juv. \& Dom. Rel. C. 1961), Santos v Goldstein 227 N.Y.S.2d 450 (NY 1962), In re Clark 185 N.E.2d 128 (OH C. of Corn. P1., Div. Of Dom. Rel. 1962), Jehovah's Witnesses v King County Hospital 278 F. Supp. 488 (W.D. Wash. 1967) aff'd 390 U.S. 598 (1968), In re Green 448 Pa. 338, 292 A.2d 387 (PA Supreme Court, 1972), In re Sampson 317 N.Y.S.2d 641 (NY Fain. C. 1970), Muhlenberg Hospital v Patterson 320 A.2d 518 (NJ Sup. C., Law D. 1974), In Interest of lvey 318 So.2d 53 (FL D.C. of A., 1 Dist 1975), In the Matter of Tara Cabrera, a Minor 552 A.2d 1114 (Pa. Super. 1989, In the Interest of JV, a Child 516 So.2d 1133, In the Matter of Baby Girl Newton 1990 WL 54916 (Del.Ch.) (unpublished opinion), In the Matter of Elisha McCauley 565 N.E.2d 411 (Mass. 1991), Cooper v Wiley 513 N.Y.S.2d 151 (A. D. 1 Dept. 1987).

$10 \operatorname{Re} O$ (A Minor) (Medical Treatment) [1993] 1 FCR 925, [1993] 2 FLR 149, $\operatorname{Re}$ $S$ (A Minor) (Medical Treatment) [1993] 1 FLR 376, Re R (A Minor) (Blood Transfusion) [1993] 2 FCR 544

11 Birkett $v$ Director General of Family and Community Services (Unreported decision of Supreme Court of New South Wales, 3 Feb. 1994, No. 3161 of 1991), Dalton v Skuthorpe (unreported decision of Supreme Court of New South Wales, 17 Nov. 1992, No. 5094 of 1992, Marchant v Finney (unreported decision of Supreme Court of New South Wales, 31 July 1992 No. 3599 of 1992), Director General, Department of Community Services Plaintiff and BB Defendants [1999] NSWSC 1169 (19 November 1999).

12 Custody of a Minor 375 Mass. 733, 379 N.E.2d 1053 (1978).

13 Prince v Massachusetts (1944) 321 US 158, Custody of a Minor 375 Mass. 733, 379 N.E.2d 1053 (1978)

14 Prince v Massachusetts (1944) 321 US 158, Jacobson v Massachusetts 197 U.S. 11 (1905).

15 Re L. D.K.; Children's Aid Society of Metropolitan Toronto v K and K (1985) 48 R.F.L. (2d) 164, 23 C.R.R 337, Re Y.(A.) (1993) 111 Nfld. \& P.E.I.R 91, 348 A.P.R. 91, Walker (Litigation Guardian of) v Region 2 Hospital Corp. (1994) 4 RFL $\left(4^{\text {th }}\right) 321,116$ DLR (4th) 477, 150 NBR (2d) 366,385 APR 366

$16 H(T) \vee$ Children's Aid Society of Metropolitan Toronto (1996) 138 DLR (4th) 144 (sub nom. Children's Aid Society of Metropolitan Toronto v TH) 9 OTC 274, 37 CRR (2d) 270, U (C. )(Next Friend of) v Alberta (Director of Child Welfare), 2000 ABQB 626, [2001] 3 WWR 575, 273 AR 106, 87 Alta LR (3d) 144, 3 WWR 575, [2000] AJ No.1067, Alberta (Director of Child Welfare) v H (B) 2002 ABPC 39, [2002] 11 WWR 752, 6 Alta LR (4 $\left.{ }^{\text {th }}\right) 34,31$ RFL $\left(5^{\text {th }}\right) 16$.

17 In re EG 549 N.E.2d 322 at 328 (III. 1989), Belcher v Charleston Area Med. Ctr., 422 S.E.2d 827 (W. Va. 1992) and W. VA. CODE \& 16-30C-6 (1998); Cardwell v Bechtol 724 S.W.2d 739 (Tenn. 1987).

18 Age of Legal Capacity (Scotland) Act, 1991.
19 Gillick v West Norfolk and Wisbech AHA [1985] 3 All ER 402

$20 \operatorname{Re} R$ (A Minor)(Wardship: Consent to Medical Treatment) [1992] Fam. 11, Re W (A Minor)(Medical Treatment: Court's Jurisdiction) [1993] Fam, 64, Re S (A Minor)(Wardship: Medical Treatment) [1994] 2 FLR 1065, Re E (A Minor)(Wardship: Medical Treatment) [1993] 1 FLR 386, Re L (Medical Treatment: Gillick Competence) [1999] 2 FCR 524, [1998] 2 FLR 810.

$21 \operatorname{Re} E$ (A Minor)(Wardship: Medical Treatment) [1993] 1 FLR 386, Re S (A Minor)(Wardship: Medical Treatment) [1994] 2 FLR 1065, Re L (Medical Treatment: Gillick Competence) [1999] 2 FCR 524, [1998] 2 FLR 810.

22 Annotation. Religion as a Factor in Child Custody and Visitation Cases 22 ALR 4th 971 (1983).

23 Erickson v Dilgard 252 N.Y.S.2d 705 (NY 1962).

24 Application of President and Dir of Georgetown College, 331 F.2d 1000 (D.C.Cir. 1964), cert. Denied 377 U.S. 978 (1964), Raleigh Fitkin-Paul Morgan Memorial Hospital v Anderson 201 A.2d 537 (NJ 1964).

25 Powell v Columbian Presbyterian Medical Center 267 N.Y.S.2d 450 (NY 1965).

26 John F. Kennedy Memorial Hospital v Heston 279 A.2d 670 (NJ 1971).

27 In re Estate of Dorone 517 Pa. 3, 534 A.2d 452 (1987), Werth v Taylor 475 N.W.2d 426 (Mich. App. 1991), In the Matter of Alice Hughes 611 A.2d 1148 (N.J.Super.A.D. 1992)

28 In re Conroy 98 NJ 321, 486 A.2d 1209 (1985).

29 In re Brown 478 So.2d 1033 (MS 1985).

30 In re Brown 478 So.2d 1037 (MS 1985)

31 Public Health Trust $v$ Wons 500 So. 2d 679 Public Health Trust $v$ Wons aff'd 541 So. 2d 96 (Fla. 1989), In re Duran 769 A. 2d 497 (Sup. Ct. Penn 2001).

32 Sidaway v Board of Governors of the Bethlem Royal Hospital and the Maudsley Hospital [1985] AC 871, 904F.

33 In Re T (Adult: Refusal of Treatment) [1993] Fam 95 at 121H (per Lord Justice Staughton).

34 Culver, CM. Advance Directives. Psychology, public policy and law 1998;4:676-87.

35 The Voluntary Euthanasia Society. Living wills. www.ves.org.uk/DebLivWill.html.

36 Watchtower Bible and Tract Society of Pennsylvania. Jehovah's Witness blood refusal card. New York: Watchtower Bible and Tract Society of New York, Inc, 1998

37 Watchtower Bible and Tract Society of Pennsylvania. How can blood save your life? New York: Watchtower Bible and Tract Society of New York, Inc, 1990.

38 Ridley DT. Honoring Jehovah's Witnesses' advance directives in emergencies: a response to Drs Migden and Braen. Acad Emerg Med 1998;5:824-35, quoting Prosser and Keeton on the Law of Torts Section 18, at 117 (5th ed, 1984).

39 Ridley DT. Honoring Jehovah's Witnesses' advance directives in emergencies: a response to Drs. Migden and Braen. Acad Emerg Med. 1998;5: 824-35, quoting President's Commission for the Study of Ethical Problems in Medicine, Making Healthc Decis 1982;93.

40 In re Estate of Darrell Dorone 534 A.2d 452 (Pa. 1987), Malette v Shulman 72 O.R.2d 417 (Ont. Ct. App. 1990)

41 In re Estate of Darrell Dorone 534 A.2d 452 (Pa. 1987)

42 In re Estate of Darrell Dorone 534 A.2d 452 (Pa. 1987.; "The emergency exception applies when immediate treatment is required to preserve life or prevent...serious impairment... but consent cannot be obtained from a patient... and there is no indication that the treatment would be refused were the patient...able to make his or her wishes known. ".

43 Malette $v$ Shulman 72 O.R. 2d 417: "the doctor could administer blood transfusions without incurring liability... if he had no reason to believe that the patient, if she had the opportunity to consent, would decline..., If he knows that the patient has refused to consent to the proposed procedure, he is not empowered to overrule the patient's decision by substituting his decision for hers even though he, and most others, may think hers a foolish or unreasonable decision"., (Ont. Ct. App. 1990).

44 Malette v Shulman 72 O.R.2d 417 (Ont. Ct. App. 1990) at 431

45 HE v A Hospital NHS Trust [2003] EWHC 1017 (Fam), [2003] 2 FLR 408, [2003] Fam Law 733. 